\title{
Choroid Plexus Meningioma
}

National Cancer Institute

\section{Source}

National Cancer Institute. Choroid Plexus Meningioma. NCI Thesaurus. Code C4719.

A meningioma that affects the choroid plexus. 